\title{
New Aspect of Bone Morphogenetic Protein Signaling and Its Relationship with Wnt Signaling in Bone
}

\author{
Nobuhiro Kamiya \\ Center for Excellence in Hip Disorders, \\ Texas Scottish Rite Hospital for Children, Dallas, Texas, \\ USA
}

\section{Introduction}

Bone morphogenetic proteins (BMPs) were discovered and named in 1965 by Marshall Urist, who initially identified the ability of an unknown factor in bone to induce ectopic bones in muscle ${ }^{1}$. In the last 45 years, the osteogenic function of BMPs has been extensively examined, mainly using osteoblasts in culture with exogenous treatments of BMPs ${ }^{2}$. Based on their potent osteogenic abilities, clinical trials have been initiated to use BMP2 and BMP7 to improve fracture repair ${ }^{2}$. The FDA (Food and Drug Administration) has approved BMP2 and BMP7 for clinical use in long bone open-fractures, non-union fractures and spinal fusion. However, recent clinical/pre-clinical studies have shown a negative impact of BMPs on bone formation under certain physiological conditions ${ }^{3-7}$, challenging the current dogma. This book chapter will focus on the recent findings of roles of BMP signaling in bone including its relationship with Wnt signaling through Wnt (Wngless, Int-1) receptor SOST (Sclerostin) and DKK1 (Dickkopf1). This new molecular interaction would explain the negative outcomes of BMP's therapy in orthopaedics.

\section{Signaling by BMPs}

Marshall Urist made the key discovery that demineralized bone matrix induced bone formation in $1965^{1}$. It took another 24 years for BMPs to be discovered. The combined works of several researchers led to the isolation of BMPs and later the cloning $8-11$. BMPs belong to the transforming growth factor- $\beta$ (TGF- $\beta$ ) gene superfamily ${ }^{12}$. Like other members of the TGF- $\beta$ family, BMPs signal through transmembrane serine/threonine kinase receptors such as BMP type I and type II receptors. Upon ligand binding, type I and II receptors form hetero-multimers 13, and the type II receptor phosphorylates and activates a highly conserved glycine- and serine-rich domain (TTSGSGSG) called a GS box between the transmembrane and kinase domains in the type I receptor. The activated BMP type I receptors relay the signal to the cytoplasm through the Smad (Sma and Mad related protein) pathway by phosphorylating their immediate downstream targets, receptor-regulated Smads (R-Smads; Smad1, Smad5, and Smad8) proteins, which then interact with co-Smad (Smad4) protein and translocate into the nucleus ${ }^{14}$. It is also known that non-Smad 
pathways through p38 MAPK (mitogen-actiated protein kinase) and TAK1 (Transforming growth factor $\beta$-activated kinase 1) are also involved in the BMP signaling ${ }^{15}$. There are three type I receptors [BMPRIA (BMP receptor type IA, ALK3), BMPRIB (BMP receptor type IB, ALK6) and ACVRI (Activin receptor type I, ALK2) and three type II receptors [BMPRII (BMP receptor type II), ACVRIIA (Activin receptor type IIA) and ACVRIIB (Activin receptor type IIB)], and approximately 30 ligands are identified 16 . Type I receptor ACVRI was originally described as an activin receptor, but it is now believed to be a receptor for BMPs. In osteoblasts, BMP2, BMP4, BMP6 and BMP7 and their receptors BMPRIA and ACVRI are abundantly expressed ${ }^{17}$. BMPRIA is a potent receptor of BMP2 and BMP4 ${ }^{18,19}$, as is ACVRI for BMP7 ${ }^{20}$. In addition, BMP antagonists Noggin, Chordin, and Gremlin were identified in osteoblasts ${ }^{21}$. These antagonists fine-tune BMP signaling in osteoblasts, as BMPs upregulate expression levels of antagonists while inducing BMP signaling 22 (Table 1, Figure 1).

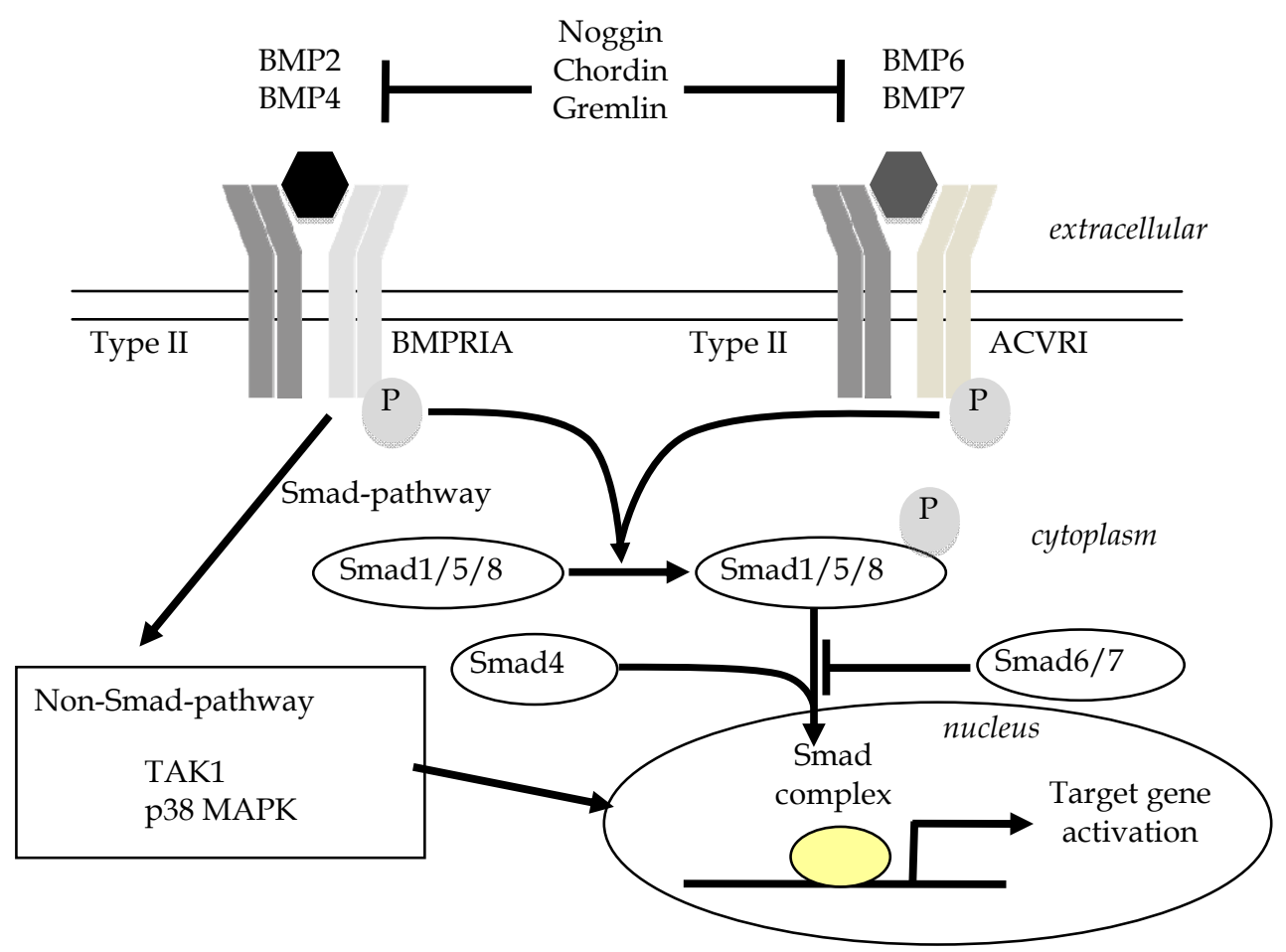

Fig. 1. Potential molecular interaction of BMP signaling in osteoblasts. BMP2, BMP4, BMP6, and BMP7 are osteoinductive and are expressed by osteoblasts. BMP2 and BMP4 are potent ligands for BMPRIA as are BMP6 and BMP7 for ACVRI. Canonical BMP signaling is through the Smad pathway via Smad1, Smad5, and Smad8 (i.e. Smad1/5/8-Smad4 complex), while non-canonical BMP signaling is through non-Smad pathways including TAK1 and p38 MAPK. Target genes are activated by these two pathways in osteoblasts. 


\begin{tabular}{|c|c|}
\hline Antagonists & Noggin, Chordin, Gremlin \\
\hline Ligands & BMP2, BMP4, BMP6, BMP7 \\
\hline Type I Receptors & BMPRIA/ALK3, ACVRI/ ALK2, (BMPRIB/ ALK6) \\
\hline Type II Receptors & BMPRII, ActRIIA, ActRIIB \\
\hline R-Smad & Smad1, Smad5, Smad8 \\
\hline Co-Smad & Smad4 \\
\hline Non-Smad Pathways & p38 MAPK, TAK1 \\
\hline
\end{tabular}

Table 1. Osteogenic BMPs and their signaling cascades in osteoblasts

\section{Molecular interaction of BMP and Wnt}

In addition to BMP signaling, Wnt signaling has been examined for a decade because of its role in bone formation and bone mass ${ }^{23-27}$. The physiological impact of Wnt signaling on bone mass was first reported in 2001, by showing that loss-of-function mutations in the coreceptor LRP5 (Low-density lipoprotein receptor-related protein 5) cause the autosomal recessive disorder osteoporosis-pseudoglioma syndrome (OPPG), a low bone mass phenotype in humans ${ }^{28}$. The importance of other Wnt ligands and receptors as bone mass effectors has been documented using genetic approaches for DKK1 29, DKK2 30, sFRPs (secreted frizzled-related proteins) 31, Sost/sclerostin 32, Lrp5 33, 34 and Lrp6, all of which are expressed in osteoblasts. However, changes in BMP signaling in bone had not been reported in Wnt-related mutations in mice.

\subsection{In vitro relationship}

In vitro experiments using pluripotent mesenchymal cell lines or primary osteoblasts to test the interaction between BMP and Wnt signaling in osteoblasts have yielded both synergistic and antagonistic results: the treatment of $\mathrm{C} 2 \mathrm{C} 12$ cells and primary osteoblasts with BMP2 induced Wnt3a expression and stabilized Wnt/ $\beta$-catenin signaling $35-37$. The treatment of C3H10T1/2 cells with Wnt3a induced the BMP4 expression levels 38. These suggest a positive autocrine loop ${ }^{37,39}$. In contrast, inhibition of BMP signaling by treatment of primary osteoblasts with dorsomorphin, an inhibitor of BMP type I receptors, increased canonical Wnt signaling ${ }^{40}$. Treatment of $\mathrm{C} 2 \mathrm{C} 12$ cells with Wnt3a repressed BMP2-dependent Id1 (Inhibitor of DNA binding 1) expression ${ }^{41}$. Similarly, treatment of cultured skull bone with BMP antagonist Noggin increased canonical Wnt signaling 42. Moreover, one study investigated intracellular cross-talk between BMP and Wnt pathways using uncommitted bone marrow stromal cells and provided a potential mechanism whereby BMP-2 antagonizes Wnt3a-induced proliferation in osteoblast progenitors by promoting an interaction between Smad1 and Dvl-1 [i.e. the human homolog of the Drosophila dishevelled gene (dsh) 1] that restricts $W n t / \beta$-catenin activation ${ }^{43}$. Another interaction via Pten (phosphatase and tensin homolog)-Akt pathway has been reported in hair follicle stem/progenitor cells ${ }^{44}$; however, it is less likely in osteoblasts ${ }^{45}$. Taken together, there seems to be both positive and negative feedback loops between the two signaling pathways (Figure 2). 
1) Positive loop

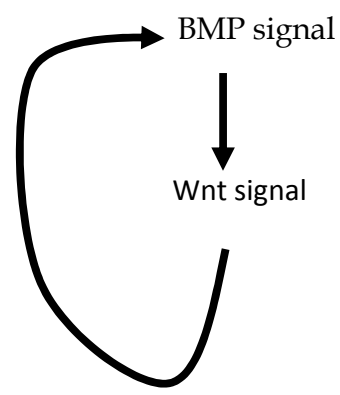

2) Negative loop

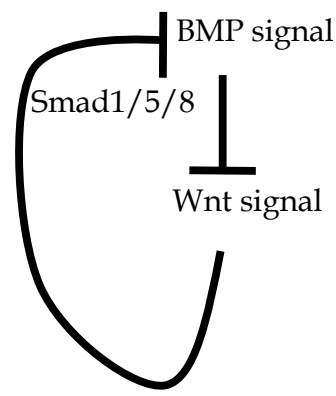

Fig. 2. A potential relationship between the two major signaling BMP and Wnt in osteoblasts based on in vitro studies. 1) Both signaling pathways function in a positive loop. 2) Both signaling pathways function in a negative loop. It is expected that these two signaling pathways may regulate each other in an age-dependent and context-dependent manner. Further studies are desired to investigate the details of each condition.

\subsection{In vivo relationship}

In vivo, only a few studies have revealed a link between the two signaling pathways. We recently found that loss-of-function of BMP signaling in osteoblasts via BMPRIA upregulates canonical Wnt signaling during embryonic and postnatal bone development, suggesting a negative regulation of Wnt signaling by BMP 40,42 . In these studies, we found that upregulation of Wnt signaling is at least in part mediated by suppression of Wnt inhibitors Sost/sclerostin and Dkk1, and both Sost/sclerostin and Dkk1 are direct targets of BMP signaling. In addition, Sost expression was severely downregulated in Bmpr1a-deficient bones as assessed by microarray analysis ${ }^{42}$. Interestingly, both Smad-dependent and Smadindependent pathways appear to contribute to the Dkk1 expression, whereas Sost/sclerostin requires only Smad-dependent signaling, suggesting differential regulation of these genes by the BMP signaling via BMPRIA ${ }^{40}$. BMP and Wnt signaling regulate the development and remodeling of many tissues and interact synergistically or antagonistically in a context- and age-dependent manner in vivo ${ }^{46,47}$. It is possible that in bone, BMP signaling inhibits Wnt signaling by upregulating the Sost/sclerostin expression in osteoblasts (Figure 3).

\subsection{SOST/Sclerostin and DKK1}

Both SOST and DKK1 are inhibitors for canonical Wnt signaling and have been highlighted because neutralizing antibodies for SOST (AMG785) and DKK1 (BHQ880) have been developed as bone anabolic agents and these potential drugs are under clinical trial ${ }^{48}$. It is known that both Dkk1 and Sost/sclerostin inhibit Wnt/ $\beta$-catenin signaling by binding to coreceptors. As both Dkk1 and Sost/sclerostin are secreted proteins expressed by osteoblasts, their role in regulating bone mass has been investigated using human and mouse genetic approaches. 


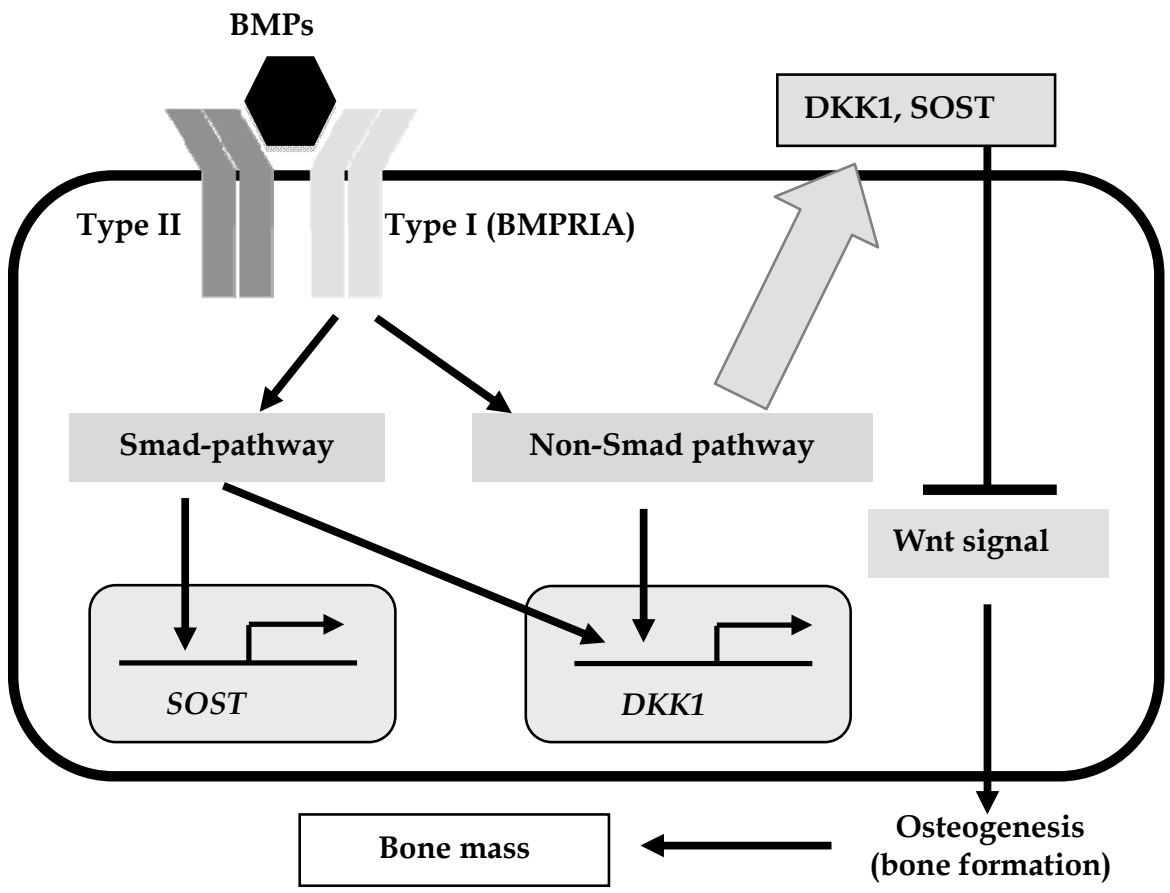

Fig. 3. Possible regulation between BMP and Wnt in Osteoblasts. A proposed model of the relationship between the BMP signaling via BMPRIA and the canonical Wnt signaling in osteoblasts. Both Dkk1 and sclerostin/Sost are downstream targets of the BMP signaling. The BMP signaling upregulates the Sost expression primarily through the Smad-dependent signaling while it upregulates the Dkk1 expression through both the Smad and non-Smad signaling (p38 MAPK). As Dkk1 and sclerostin/Sost act as Wnt signaling inhibitors, BMP signaling in osteoblasts, in turn, leads to a decrease in osteogenesis and bone mass. Dkk1 and sclerostin/Sost play an important role in regulating bone mass as downstream effectors of BMPRIA signaling in bone taking balances between BMP signaling and Wnt signaling.

\subsubsection{SOST/Sclerostin}

Sost/sclerostin was originally reported as a member of the BMP antagonist DAN family (i.e. the Dan gene family of BMP antagonists) ${ }^{49,50}$. Although DAN family members modulate both BMP and Wnt signaling in Xenopus $51-53$, recent studies suggest a primary role of Sost/sclerostin in Wnt signaling in mouse and humans: Sost/sclerostin is not a BMP antagonist 54 but rather a Wnt inhibitor 55 that binds the Wnt co-receptor low density lipoprotein receptor-related protein 5 and 6 (LRP5 and LRP6) ${ }^{32,56}$. Conventional knockouts of Sost (i.e. Sost $\mathrm{KO}$ ) are viable and exhibit increased bone mass ${ }^{57}$. In humans, loss-offunction and hypomorphic mutations in SOST cause sclerosteosis 58, 59 and Van Buchem disease 60,61 , respectively, with a high bone mass (HBM) phenotype. These mutants share the HBM phenotype with other gain-of-function of LRP5 mutation, due to the defect in DKK1mediated regulation of LRP5 in humans ${ }^{62-64}$ and overexpression of Lrp5 in mice ${ }^{65}$. In 
contrast, loss-of-function of LRP5 leads to OPPG with low bone mass 28 , which is similar to the bone phenotype of mice overexpressing Sost 50 . In addition, recent genome-wide SNPbased analyses identified a significant association between bone mineral density and the SOST gene locus 66-68.

\subsubsection{DKK1}

Conventional knockouts of $D k k 1$ die in utero from defective head induction and limb formation ${ }^{29}$. Similar to Sost KO mice, mice heterozygous for $D k k 1$ ( $D k k 1^{+/-}$mice), however, exhibit a high bone mass (HBM) phenotype ${ }^{69}$, while overexpression of $D k k 1$ in osteoblasts causes osteopenia ${ }^{70}$. In addition, increased $D K K 1$ expression in bone marrow has also been associated with lytic bone lesions in patients with multiple myeloma ${ }^{71}$. Collectively, these results support the hypothesis that Dkk1 functions as a potent negative regulator of bone mass.

\subsubsection{Sost/DKK1 expression in the Bmpr1a cKO mice}

Conditional knockouts of Bmpr1a, which are deficient in the Dkk1 and Sost expression, show a HBM phenotype 40, 42, 72. In particular, Sost expression levels were the most dramatically reduced in the $\mathrm{cKO}$ mice during embryonic stages ${ }^{42}$. Furthermore, both Sost and Dkk1 expression levels were increased by the addition of BMP2, a potent ligand for BMPRIA, using primary osteoblasts ${ }^{40}$. Similarly, both Sost and Dkk1 expression levels were significantly reduced in the Acvr1 cKO mice ${ }^{73}$. In addition, both Sost and Dkk1 expression levels were increased by the addition of BMP7, a potent ligand for ACVRI, using primary osteoblasts 73 . These facts support the new concept of molecular interactions between BMP signaling and Wnt signaling that Dkk1 and Sost/sclerostin act physiologically as inhibitors of canonical Wnt signaling as downstream targets of BMP receptors BMPRIA and ACVRI and that BMP signaling can negatively controls Wnt signaling in osteoblasts (Figure 3).

\subsection{Effects of Wnt signaling on osteoclasts}

There is accumulating evidence that Wnt signaling also plays a critical role in osteoclastogenesis regulated by osteoblasts through the RANKL (Receptor activator of nuclear factor kappa-B ligand)-OPG (Osteoprotegerin) pathway. Recently, two in vivo studies have suggested that the canonical Wnt signaling is important in the regulation of osteoclastogenesis by osteoblasts. One study provided evidence that the Wnt pathway positively regulates the expression of $O p g$ in osteoblasts ${ }^{74}$. Overexpression of stabilized $\beta$ catenin in osteoblasts, which results in an increase of canonical Wnt signaling level, decreases osteoclast differentiation leading to increased bone volume in mice ${ }^{74}$. Another study showed that an osteoblast-specific deletion of $\beta$-catenin leads to an impaired maturation and mineralization of bones in mice due to the elevated expression of Rankl and diminished Opg 75 . These facts suggest that the canonical Wnt pathway negatively regulates osteoblasts in their supporting function in osteoclastogenesis, and thus upregulation of Wnt signaling in osteoblasts can suppress osteoclast-mediated bone resorption ${ }^{75}$. Taken together, it is possible that the treatment of bones with BMPs can reduce Wnt activity in osteoblasts and in turn enhance osteoclast activity. 


\section{BMP signaling and mouse genetics}

Along with the huge advancement in technologies involving mouse genetics over the last decade, many of the BMP signaling related genes have been knocked out in mice. BMP2, BMP4, BMP6 and BMP7 and their receptor BMPRIA and ACVRI are abundantly expressed in bone. However, conventional knockout mice for these genes result in an early embryonic lethality and thus, it is not possible to investigate bone development and remodeling using these models $76-82$. To avoid the embryonic lethality, a strategy of conditional knockout mice using a Cre-loxP system has been employed. A bone-specific conditional deletion of Bmpr1a using an $\mathrm{Og} 2-\mathrm{Cre}$ mouse, in which a Cre recombination is restricted in differentiated osteoblasts under the osteocalcin promoter, was first reported in $2004{ }^{83}$. Interestingly, this study demonstrated that the response of osteoblasts to BMP signaling is age-dependent; in the mutant mice, bone volume decreased in young mice but increased in aged mice. In addition, the activity of osteoclasts was reduced in the aged osteoblast-specific Bmpr1adeficient mice, which may have lead to the complex skeletal phenotype. These facts suggest that the BMP signaling in differentiated osteoblasts can control the balance between bone formation by osteoblasts and resorption by osteoclasts, thereby affecting the final outcome of the amount of bone mass in an age-dependent manner. The increased bone mass in the Bmpr1a-deficient mice appeared to be in opposition to the general concept of BMPs as osteogenic inducers; however, the concept is reasonable if the target cell for BMPs as osteogenic inducers is mesenchymal cells or chondrocytes,. It is expected that BMPs have multifaceted functions in vivo because different cell types exhibit differing responses to BMPs. In addition, the opposite outcome in the Bmpr1a-deficient mice was discussed from the point of molecular interaction in the sections 3.

\subsection{BMP signaling in chondrocytes, mesenchymal cells, and osteoblasts}

During skeletogenesis, bones are formed via two distinct processes: intramembranous and endochondral bone formation ${ }^{84}$. Intramembranous bone formation occurs primarily in flat bones (e.g., calvarial bones) where mesenchymal cells differentiate directly into osteoblasts 85. Endochondral bone formation occurs primarily in long bones where condensed mesenchymal cells differentiate into chondrocytes to form cartilage templates, and then chondrocytes are replaced by osteoblasts ${ }^{86}$. Recently many studies have been designed to investigate the difference in the molecular mechanism by which BMP signaling regulates these cell types. Several Cre mouse lines have been used to target different cell types including osteoblast, chondrocyte, and mesenchymal cells (Table 2). BMP signaling in chondrocytes and mesenchymal cells both positively control bone size and mass while BMP signaling in osteoblasts can reduce them.

\subsubsection{Chondrocytes}

There are several lines of evidence that show that BMP signaling in chondrocytes is required for bone size and the amount of bone mass. BMP signaling through BMPRIA is essential for postnatal maintenance of articular cartilage, using a Gdf5-Cre mouse line specific for chondrocytes in joints ${ }^{87}$. Similarly, the critical role of Bmpr1a together with Bmpr1b in chondrocytes during endochondral bone formation using a Col2-Cre mouse line was reported. ${ }^{88}$. Moreover, in chondrocytes a simultaneous deficiency in Smad 1 and Smad 5, 


\begin{tabular}{|c|c|c|c|c|c|}
\hline & $\begin{array}{c}\text { Promoter } \\
\text { Cre- } \\
\text { mouse }\end{array}$ & BMP signal & Stage & Bone mass & Ref. \\
\hline \multicolumn{6}{|l|}{ Chondrocyte } \\
\hline Bmpr1a cKO & Gdf5-Cre & down & $\begin{array}{c}\text { E12.5-E16.5, } \\
7 \mathrm{~W}, 9\end{array}$ & Reduced & 87 \\
\hline $\begin{array}{l}\text { Double knockout of } \\
\text { Bmpr1a and Bmpr } 1 b\end{array}$ & Col2-Cre & down & E12.5-E16.5 & Reduced & 88 \\
\hline Bmp4 overexpression & Col11a2 & up & E18.5 & Increased & 89 \\
\hline Noggin overexpression & Col11a2 & down & E18.5 & Reduced & 89 \\
\hline $\begin{array}{l}\text { Double knockout of } \\
\text { Smad1 and Smad5 }\end{array}$ & Col2-Cre & down & $\begin{array}{c}\text { E12.5- } \\
\text { newborn }\end{array}$ & Reduced & 90 \\
\hline \multicolumn{6}{|l|}{ Mesenchymal cell } \\
\hline $\begin{array}{c}\text { Double knockout of } \\
B_{M P 2} \text { and } B_{M P 4}\end{array}$ & Prx1-Cre & down & $\begin{array}{c}\text { E10.5- } \\
\text { newborn, } 3 \mathrm{~W}\end{array}$ & Reduced & 91 \\
\hline Bmp2 cKO & Prx1-Cre & down & $5 \mathrm{M}$ & Reduced & 92 \\
\hline \multicolumn{6}{|l|}{ Osteoblast } \\
\hline Bmpr1a cKO & Ogl2-Cre & down & $\begin{array}{c}3 \mathrm{M} \\
10 \mathrm{M}\end{array}$ & $\begin{array}{l}\text { Reduced } \\
\text { Increased }\end{array}$ & 83 \\
\hline Bmp4 overexpression & $\begin{array}{c}2.3 \mathrm{~kb} \\
\text { Col1 }\end{array}$ & up & E18.5 & Reduced & 93 \\
\hline Noggin overexpression & $\begin{array}{c}2.3 \mathrm{~kb} \\
\text { Col1 }\end{array}$ & down & $\mathrm{E} 17.5,3 \mathrm{~W}$ & Increased & 93 \\
\hline Bmpr1a cKO & $\begin{array}{l}3.2 \mathrm{~kb} \\
\text { Col1- } \\
\text { CreER }\end{array}$ & down & $\begin{array}{l}\text { E18.5, 3W, } \\
5 \mathrm{M}\end{array}$ & Increased & $\begin{array}{c}40,42 \\
72\end{array}$ \\
\hline Acvr1 cKO & $\begin{array}{l}3.2 \mathrm{~kb} \\
\text { Col1- } \\
\text { CreER }\end{array}$ & down & $\begin{array}{l}\mathrm{E} 18.5,3 \mathrm{~W} \\
5 \mathrm{M}\end{array}$ & Increased & 73 \\
\hline \multicolumn{6}{|l|}{ Osteoclast } \\
\hline Bmpr1a cKO & Ctsk-Cre & down & $8 \mathrm{~W}$ & Increased & 94 \\
\hline
\end{tabular}

Table 2. Bone mass observed in genetically engineered mutant mice of BMP signaling

which are BMPs' downstream target molecules, reduces bone mass ${ }^{90}$. In parallel, studies focusing on BMP ligands and their antagonists provide further evidence that BMPs are critical for normal development of cartilage. A transgenic mouse line to overexpress Bmp4 in mesenchymal cells/chondrocytes using a type XI collagen promoter (Col11a2) was generated, and bone mass was increased in the mutant mice ${ }^{89}$. Another transgenic mouse line in which Noggin was overexpressed in the same cells (Col11a2-Noggin) demonstrated a decreased bone mass. As Noggin is an antagonist for BMPs (BMP2, BMP4, BMP5, BMP6, and BMP7) with various degrees of affinity 95 , these results suggest that BMP signaling positively controls proliferation and differentiation of chondrocytes. 


\subsubsection{Mesenchymal cells}

Similar to chondrocytes, a few studies demonstrated a requirement of BMP signaling in mesenchymal cells for proper bone development and remodeling using a mesenchymal cellspecific Cre mouse line, Prx1-Cre, in which Cre is active in mesenchymal cells as early as embryonic day $9.5^{96}$. Using the Prx1-Cre mouse, the simultaneously conditional deletions of Bmp2 and Bmp4 in mesenchymal cells resulted in an impairment of osteogenesis during late embryogenesis ${ }^{91,92}$. In contrast, the conditional deletion of Bmp2 in mesenchymal cells does not show overt developmental abnormalities; however, the resulted mice lack an initiation of fracture healing 91, 92. Interestingly, Bmp7-deficiency in mesenchymal cells did not affect bone mass probably due to the compensation by Bmp4 ${ }^{97}$. Taken together, it is possible that the defects in the BMP signaling in chondrocytes largely contribute to the phenotypes described above because chondrocytes are derived from mesenchymal cells and play an important role in the process of fracture repair.

\subsubsection{Osteoblasts}

As aforementioned, a differentiated osteoblast-specific deletion of Bmpr1a caused an increase in bone mass in aged mice ${ }^{83}$. Similar to this finding, an overexpression of a BMP antagonist, Noggin, in osteoblasts increases bone volume with a reduced osteoclast number and osteoclastogenesis both at embryonic day 17.5 (E17.5) and at 3 weeks ${ }^{93}$. In parallel, the overexpression of $\mathrm{Bmp} 4$ in osteoblasts reduced bone mass presumably due to the increase in the osteoclast number at E18.5 ${ }^{93}$. Recently, Bmpr1a was conditionally disrupted in immature osteoblasts using a tamoxifen inducible Cre driven by a 3.2-kb alpha1(I) collagen chain gene (Col1a1) promoter. In the mutant mice, bone mass was dramatically increased during the
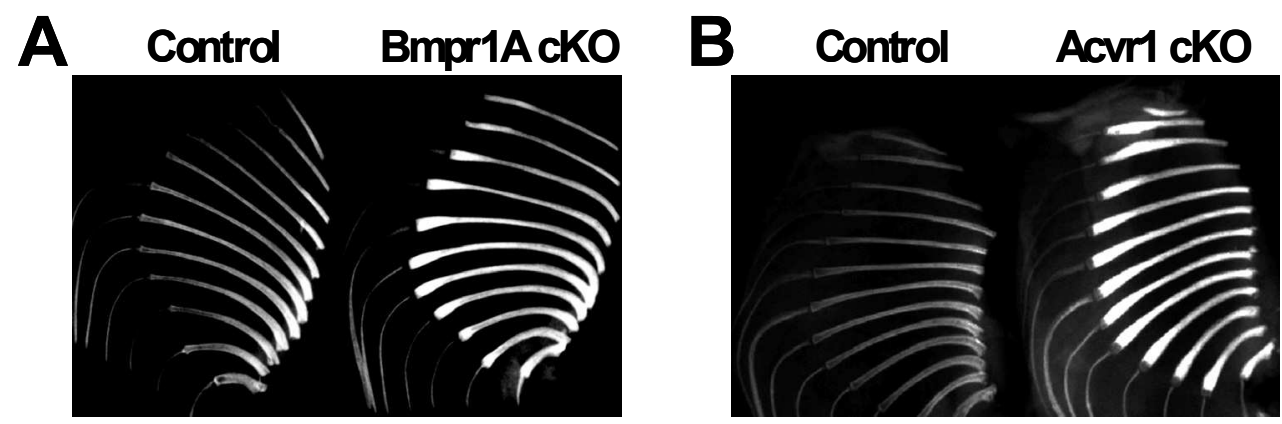

Fig. 4. Increased bone mass in the osteoblast-specific conditional knockout (cKO) mice for $\mathrm{BMP}$ receptors BMPRIA or ACVRI at the adult stage. Bmpr1a or Acvr1 cKO mice were generated by crossing a floxed mouse line for Bmpr1a(Bmpr1afx/fx) or Acvr1(Acvr1fx/fx) with a transgenic mouse line harboring a tamoxifen-inducible Cre driven by a $3.2 \mathrm{~kb}$ mouse procollagen $\alpha 1$ (I) promoter. The Cre recombination was induced specifically in the osteoblasts by 10 weeks of tamoxifen administration from 10 weeks after birth, and bones were removed at 22 weeks. Radiodensity of rib bones was assessed by X-ray. (A) The radiodensity was dramatically increased in the Bmpr1a cKO mice (Cre+, Bmpr1afx/fx) compared with controls (Cre-, Bmpr1afx/fx). (B) The radiodensity was dramatically increased in the Acvr1 cKO mice (Cre+, Acvr1fx/fx) compared with controls (Cre-, Bmpr1afx/fx). 
bone remodeling stage at 22 weeks as well as the bone developmental stages at E18.5 and 3 weeks 42, 72 (Figure 4A). This result is an interesting contrast to previous work that disruption of Bmpr1a in differentiated osteoblasts results in decrease of bone mass in young adult stages (3-4 weeks). The increased bone mass in the Bmpr1a-deficient mice resulted from severely suppressed bone resorption due to reduced osteoclastogenesis, despite a simultaneous small reduction in the rate of bone formation ${ }^{72}$. Levels of RANKL and OPG are changed in the Bmpr1a-deficient osteoblasts and fail to support osteoclastogenesis 42,72 . In addition, the conditional disruption of Acvr1 in osteoblasts also demonstrated a dramatic increase in bone mass, similar to the bone phenotype of Bmpr1a-deficient mice (Figure 4B), although osteoclastic activity is still under investigation ${ }^{73}$. These findings suggest that BMP signaling may have dual roles in osteoblasts; to stimulate both bone formation by osteoblasts and bone resorption supporting osteoclastogenesis. Disruption of BMP signaling in immature osteoblasts alters the balance of bone turn over to increase the bone mass, which is opposite to what people have expected for the past 4 decades.

\subsubsection{Other cell type}

Angiogenesis is another necessary step in new bone formation in skeletal development as well as in bone remodeling after fracture ${ }^{98,99}$. Both BMP2 and BMP7 are known to induce angiogenesis by associating with other growth factors such as VEGF (vascular endothelial growth factor), bFGF (basic fibroblast growth factor), and TGF- $\beta 1{ }^{100}$. A study using an adenovirus vector in muscle demonstrated that BMP9 induces ectopic bone formation similar to BMP2 101, 102. As BMP9 is abundantly expressed in endothelial cells that are primarily cell types for angiogenesis 103 , it is possible that BMP signaling in endothelial cells synergizes anabolic bone formation. The mechanism and origin of precursor cells for ectopic bone formation, which is physiologically observed in the patients with FOP (fibrodysplasia ossificans progressiva), is under investigation 104-106 but could be endothelial cells 107 .

\subsubsection{Possible interpretation}

Mesenchymal cells, chondrocytes, and endothelial cells respond to BMPs by inducing bone mass and size (Table 3). Recent histological findings suggest that the process of endochondral bone formation, which first forms cartilage template prior to the final bone following vessel formation (i.e. angiogenesis), plays a critical role in the process of ectopic bone formation 108 . The origin of precursor cells for the ectopic bone is under investigation 105, 106; however, it is possible that formation of ectopic bones by BMPs ${ }^{1}$ is largely due to the stimulation of chondrocytes, mesenchymal cells, and/or endothelial cells in soft tissue, which results in an expansion of ectopic cartilage subsequently replaced by osteoblasts. There is another possibility that the BMP signaling directly affects osteoblasts to form ectopic bone. However, this possibility is less likely based on recent evidence that reduced

\begin{tabular}{|c|c|}
\hline Cell types that can increase bone mass & Cell types that can reduce bone mass \\
\hline Mesenchymal cells & Osteoclasts \\
Chondrocytes & Osteoblasts \\
Osteoblasts & \\
Endothelial cells & \\
\hline
\end{tabular}

Table 3. A variety of cell types in bone that mediate bone mass in response to BMPs 
BMP signaling in osteoblasts results in an increase in bone mass. As current methods of systemic and local treatment affect multiple cell types simultaneously in bone, it is important to evaluate the effects of BMPs on more than just osteoblasts.

\subsection{Effect of BMP signaling on osteoclasts}

Bone mass is determined by the balance between bone formation and bone resorption. Osteoclasts are multinuclear cells derived from hematopoietic stem cells to secrete enzymes for bone resorption ${ }^{109}$. Recent mouse genetic studies revealed the importance of BMP signaling for osteoclastic activity and bone resorption.

\subsubsection{Regulation of osteoclast by osteoblast-dependent BMP signaling}

It is expected that BMPs play roles in osteoclastogenesis and their functions, because receptors for BMPs are expressed in these cells ${ }^{110}$. Additionally, osteoblasts also play critical roles in bone resorption by regulating osteoclastogenesis because they produce RANK ligand (RANKL), essential to promote osteoclastogenesis, and its decoy receptor, osteoprotegerin (OPG) 111, 112. A balance between RANKL and OPG is important to determine the degree of osteoclastogenesis, i.e. more RANKL production by osteoblasts leads to more osteoclasts; thus more bone resorption is expected. As RANKL is an osteoblastic product and BMPs induce osteoblast maturation, BMPs indirectly stimulate osteoclastogenesis and thus, osteoclastogenesis is impaired when osteoblastogenesis is blocked with BMP antagonists in culture ${ }^{113}$. The physiological effects of BMP signaling in osteoblasts on osteoclastogenesis were determined later using an osteoblast-specific gain-of-function or loss-of-function mouse model. For the cases of the osteoblast-specific deletion of Bmpr1a and osteoblast-specific over expression of Noggin, osteoclastogenesis is highly compromised leading to an increase of bone mass 83,93 . In contrast, osteoblast-specific overexpression of Bmp4 increased osteoclastogenesis 93. The regulation of RANKL by BMPs was suggested based on an in vitro study ${ }^{114}$. This concept was recently proven in mouse studies, as Bmpr1a-deficient osteoblasts were not able to support osteoclastogenesis due to an imbalance between RANKL and OPG 42, 72. It is therefore concluded that osteoblasts can respond to BMPs by inducing osteogenic (i.e. bone anabolic) action as well as osteoclastogenic (i.e. bone catabolic) action simultaneously presumably dependening on context and timing (Table 3).

\subsubsection{Regulation of osteoclast by osteoclast-dependent BMP signaling}

BMP receptors are expressed in osteoclasts ${ }^{110}$. When BMP signaling through BMPRIA was deficient in osteoclasts using a Catepsin $\mathrm{K}$ promoter (CtsK), bone mass was increased as expected ${ }^{94}$ (Table 2). Interestingly, both bone formation rate and osteoblast number assessed by bone histomorphometry analysis were increased while osteoclast number was reduced in the mutant mice compared to their controls. It is possible that some coupling factors can control osteoblast function in an osteoclast-dependent manner in the mutant mice (i.e. osteoclast-derived coupling factors). Further studies are needed to determine whether such factors mediate BMPRIA-induced coupling from osteoclasts to osteoblasts.

\section{Future direction of BMPs and Wnt}

As is discussed in the former part of this review, it is important to understand that BMPs have variable and context-sensitive effects on diverse cell types in bone including 
chondrocytes, osteoblasts, and osteoclasts. Studies focusing on BMP receptors in chondrocytes including mesenchymal cells suggest that these cells can respond to BMP signaling by increasing bone mass during the endochondral formation process. As discussed in the latter part, BMP signals can consistently inhibit Wnt signaling and bone mass while exerting concordant effects on Dkk1 and Sost. This revision of traditional understanding of the BMP signaling pathway in clinical therapeutics might suggest that in some circumstances, BMP inhibition would be desirable for promoting bone mass. More importantly, if BMP signaling reduces bone mass by inhibiting Wnt signaling through SOST/DKK1 in osteoblasts, small molecule antagonists for BMPs or BMP receptors can conversely increase bone mass and size. Therefore, development of these molecules would be a next step towards disease conditions in which bone mass is reduced such as osteoporosis and bone fracture. Although antibodies for SOST and DKk1 have been developed in order to increase bone mass, the small molecule antagonists which can be an upstream of SOST and DKK1 would be used as more potent therapeutic agents for osteoporosis. Last, the function of the BMP signaling in osteoclasts remains largely unknown in terms of coupling factors and merits future study, although the BMP signaling regulates osteoblast-dependent osteoclastogenesis via the RANKL-OPG pathway.

\section{Conclusion}

Understanding the complex roles of the BMP signaling pathway and its molecular interaction with other signaling pathway (i.e. Wnt) in a variety of cell-types in bone including chondrocytes, osteoblasts and osteoclasts, which contribute to normal physiological conditions (i.e. bone development, homeostasis, and remodeling) will not only help to improve current knowledge of the pathological conditions (i.e. bone fracture, osteoporosis, and other congenital and aging-related bone diseases) but may provide novel therapeutically useful strategies.

\section{Acknowledgment}

I would like to thank Drs. Yuji Mishina, Jian Q. Feng, Tatsuya Kobayashi, and Henry M. Kronenberg for the generation of multiple transgenic mouse lines and Harry K. W. Kim for encouragement. This work was supported by the Lilly Fellowship Foundation and TSRH Research Foundation (GL170999, GL171041).

\section{References}

[1] Urist, M. R., Bone: formation by autoinduction. Science 1965, 150, (698), 893-9.

[2] Simpson, A. H.; Mills, L.; Noble, B., The role of growth factors and related agents in accelerating fracture healing. J Bone Joint Surg Br 2006, 88, (6), 701-5.

[3] Aro, H. T.; Govender, S.; Patel, A. D.; Hernigou, P.; Perera de Gregorio, A.; Popescu, G. I.; Golden, J. D.; Christensen, J.; Valentin, A., Recombinant Human Bone Morphogenetic Protein-2: A Randomized Trial in Open Tibial Fractures Treated with Reamed Nail Fixation. J Bone Joint Surg Am 2011.

[4] Laursen, M.; Hoy, K.; Hansen, E. S.; Gelineck, J.; Christensen, F. B.; Bunger, C. E., Recombinant bone morphogenetic protein-7 as an intracorporal bone growth stimulator in unstable thoracolumbar burst fractures in humans: preliminary results. Eur Spine J 1999, 8, (6), 485-90. 
[5] Pradhan, B. B.; Bae, H. W.; Dawson, E. G.; Patel, V. V.; Delamarter, R. B., Graft resorption with the use of bone morphogenetic protein: lessons from anterior lumbar interbody fusion using femoral ring allografts and recombinant human bone morphogenetic protein-2. Spine (Phila Pa 1976) 2006, 31, (10), E277-84.

[6] Seeherman, H. J.; Li, X. J.; Bouxsein, M. L.; Wozney, J. M., rhBMP-2 induces transient bone resorption followed by bone formation in a nonhuman primate core-defect model. J Bone Joint Surg Am 2010, 92, (2), 411-26.

[7] Vaidya, R.; Weir, R.; Sethi, A.; Meisterling, S.; Hakeos, W.; Wybo, C. D., Interbody fusion with allograft and rhBMP-2 leads to consistent fusion but early subsidence. J Bone Joint Surg Br 2007, 89, (3), 342-5.

[8] Sampath, T. K.; Reddi, A. H., Dissociative extraction and reconstitution of extracellular matrix components involved in local bone differentiation. Proc Natl Acad Sci U S A 1981, 78, (12), 7599-603.

[9] Wozney, J. M.; Rosen, V.; Celeste, A. J.; Mitsock, L. M.; Whitters, M. J.; Kriz, R. W.; Hewick, R. M.; Wang, E. A., Novel regulators of bone formation: molecular clones and activities. Science 1988, 242, (4885), 1528-34.

[10] Luyten, F. P.; Cunningham, N. S.; Ma, S.; Muthukumaran, N.; Hammonds, R. G.; Nevins, W. B.; Woods, W. I.; Reddi, A. H., Purification and partial amino acid sequence of osteogenin, a protein initiating bone differentiation. J Biol Chem 1989, 264, (23), 13377-80.

[11] Wozney, J. M., The bone morphogenetic protein family and osteogenesis. Mol Reprod Dev 1992, 32, (2), 160-7.

[12] Massague, J., Receptors for the TGF-beta family. Cell 1992, 69, (7), 1067-70.

[13] Wrana, J. L.; Attisano, L.; Wieser, R.; Ventura, F.; Massague, J., Mechanism of activation of the TGF-beta receptor. Nature 1994, 370, (6488), 341-7.

[14] Chen, D.; Zhao, M.; Mundy, G. R., Bone morphogenetic proteins. Growth Factors 2004, $22,(4), 233-41$.

[15] Shim, J. H.; Greenblatt, M. B.; Xie, M.; Schneider, M. D.; Zou, W.; Zhai, B.; Gygi, S.; Glimcher, L. H., TAK1 is an essential regulator of BMP signalling in cartilage. EMBO J 2009, 28, (14), 2028-41.

[16] Wagner, D. O.; Sieber, C.; Bhushan, R.; Borgermann, J. H.; Graf, D.; Knaus, P., BMPs: from bone to body morphogenetic proteins. Sci Signal 2010, 3, (107), mr1.

[17] Lavery, K.; Swain, P.; Falb, D.; Alaoui-Ismaili, M. H., BMP-2/4 and BMP-6/7 differentially utilize cell surface receptors to induce osteoblastic differentiation of human bone marrow-derived mesenchymal stem cells. J Biol Chem 2008, 283, (30), 20948-58.

[18] Keller, S.; Nickel, J.; Zhang, J. L.; Sebald, W.; Mueller, T. D., Molecular recognition of BMP-2 and BMP receptor IA. Nat Struct Mol Biol 2004, 11, (5), 481-8.

[19] Hatta, T.; Konishi, H.; Katoh, E.; Natsume, T.; Ueno, N.; Kobayashi, Y.; Yamazaki, T., Identification of the ligand-binding site of the BMP type IA receptor for BMP-4. Biopolymers 2000, 55, (5), 399-406.

[20] Macias-Silva, M.; Hoodless, P. A.; Tang, S. J.; Buchwald, M.; Wrana, J. L., Specific activation of Smad1 signaling pathways by the BMP7 type I receptor, ALK2. J Biol Chem 1998, 273, (40), 25628-36.

[21] Rosen, V., BMP and BMP inhibitors in bone. Ann N Y Acad Sci 2006, 1068, 19-25. 
[22] Gazzerro, E.; Gangji, V.; Canalis, E., Bone morphogenetic proteins induce the expression of noggin, which limits their activity in cultured rat osteoblasts. J Clin Invest 1998, 102, (12), 2106-14.

[23] Baron, R.; Rawadi, G.; Roman-Roman, S., Wnt signaling: a key regulator of bone mass. Curr Top Dev Biol 2006, 76, 103-27.

[24] Glass, D. A., 2nd; Karsenty, G., Molecular bases of the regulation of bone remodeling by the canonical Wnt signaling pathway. Curr Top Dev Biol 2006, 73, 43-84.

[25] Harada, S.; Rodan, G. A., Control of osteoblast function and regulation of bone mass. Nature 2003, 423, (6937), 349-55.

[26] Hartmann, C., A Wnt canon orchestrating osteoblastogenesis. Trends Cell Biol 2006, 16, (3), 151-8.

[27] Krishnan, V.; Bryant, H. U.; Macdougald, O. A., Regulation of bone mass by Wnt signaling. J Clin Invest 2006, 116, (5), 1202-9.

[28] Gong, Y.; Slee, R. B.; Fukai, N.; Rawadi, G.; Roman-Roman, S.; Reginato, A. M.; Wang, H.; Cundy, T.; Glorieux, F. H.; Lev, D.; Zacharin, M.; Oexle, K.; Marcelino, J.; Suwairi, W.; Heeger, S.; Sabatakos, G.; Apte, S.; Adkins, W. N.; Allgrove, J.; ArslanKirchner, M.; Batch, J. A.; Beighton, P.; Black, G. C.; Boles, R. G.; Boon, L. M.; Borrone, C.; Brunner, H. G.; Carle, G. F.; Dallapiccola, B.; De Paepe, A.; Floege, B.; Halfhide, M. L.; Hall, B.; Hennekam, R. C.; Hirose, T.; Jans, A.; Juppner, H.; Kim, C. A.; Keppler-Noreuil, K.; Kohlschuetter, A.; LaCombe, D.; Lambert, M.; Lemyre, E.; Letteboer, T.; Peltonen, L.; Ramesar, R. S.; Romanengo, M.; Somer, H.; SteichenGersdorf, E.; Steinmann, B.; Sullivan, B.; Superti-Furga, A.; Swoboda, W.; van den Boogaard, M. J.; Van Hul, W.; Vikkula, M.; Votruba, M.; Zabel, B.; Garcia, T.; Baron, R.; Olsen, B. R.; Warman, M. L., LDL receptor-related protein 5 (LRP5) affects bone accrual and eye development. Cell 2001, 107, (4), 513-23.

[29] Mukhopadhyay, M.; Shtrom, S.; Rodriguez-Esteban, C.; Chen, L.; Tsukui, T.; Gomer, L.; Dorward, D. W.; Glinka, A.; Grinberg, A.; Huang, S. P.; Niehrs, C.; Izpisua Belmonte, J. C.; Westphal, H., Dickkopf1 is required for embryonic head induction and limb morphogenesis in the mouse. Dev Cell 2001, 1, (3), 423-34.

[30] Li, X.; Liu, P.; Liu, W.; Maye, P.; Zhang, J.; Zhang, Y.; Hurley, M.; Guo, C.; Boskey, A.; Sun, L.; Harris, S. E.; Rowe, D. W.; Ke, H. Z.; Wu, D., Dkk2 has a role in terminal osteoblast differentiation and mineralized matrix formation. Nat Genet 2005, 37, (9), 945-52.

[31] Bodine, P. V.; Zhao, W.; Kharode, Y. P.; Bex, F. J.; Lambert, A. J.; Goad, M. B.; Gaur, T.; Stein, G. S.; Lian, J. B.; Komm, B. S., The Wnt antagonist secreted frizzled-related protein-1 is a negative regulator of trabecular bone formation in adult mice. Mol Endocrinol 2004, 18, (5), 1222-37.

[32] Li, X.; Zhang, Y.; Kang, H.; Liu, W.; Liu, P.; Zhang, J.; Harris, S. E.; Wu, D., Sclerostin binds to LRP5/ 6 and antagonizes canonical Wnt signaling. J Biol Chem 2005, 280, (20), 19883-7.

[33] Ai, M.; Holmen, S. L.; Van Hul, W.; Williams, B. O.; Warman, M. L., Reduced affinity to and inhibition by DKK1 form a common mechanism by which high bone massassociated missense mutations in LRP5 affect canonical Wnt signaling. Mol Cell Biol 2005, 25, (12), 4946-55.

[34] Patel, M. S.; Karsenty, G., Regulation of bone formation and vision by LRP5. N Engl J Med 2002, 346, (20), 1572-4. 
[35] Bain, G.; Muller, T.; Wang, X.; Papkoff, J., Activated beta-catenin induces osteoblast differentiation of $\mathrm{C} 3 \mathrm{H} 10 \mathrm{~T} 1 / 2$ cells and participates in BMP2 mediated signal transduction. Biochem Biophys Res Commun 2003, 301, (1), 84-91.

[36] Mbalaviele, G.; Sheikh, S.; Stains, J. P.; Salazar, V. S.; Cheng, S. L.; Chen, D.; Civitelli, R., Beta-catenin and BMP-2 synergize to promote osteoblast differentiation and new bone formation. J Cell Biochem 2005, 94, (2), 403-18.

[37] Chen, Y.; Whetstone, H. C.; Youn, A.; Nadesan, P.; Chow, E. C.; Lin, A. C.; Alman, B. A., Beta-catenin signaling pathway is crucial for bone morphogenetic protein 2 to induce new bone formation. J Biol Chem 2007, 282, (1), 526-33.

[38] Winkler, D. G.; Sutherland, M. S.; Ojala, E.; Turcott, E.; Geoghegan, J. C.; Shpektor, D.; Skonier, J. E.; Yu, C.; Latham, J. A., Sclerostin inhibition of Wnt-3a-induced C3H10T1/2 cell differentiation is indirect and mediated by bone morphogenetic proteins. J Biol Chem 2005, 280, (4), 2498-502.

[39] Rawadi, G.; Vayssiere, B.; Dunn, F.; Baron, R.; Roman-Roman, S., BMP-2 controls alkaline phosphatase expression and osteoblast mineralization by a Wnt autocrine loop. J Bone Miner Res 2003, 18, (10), 1842-53.

[40] Kamiya, N.; Kobayashi, T.; Mochida, Y.; Yu, P. B.; Yamauchi, M.; Kronenberg, H. M.; Mishina, Y., Wnt Inhibitors Dkk1 and Sost are Downstream Targets of BMP Signaling Through the Type IA Receptor (BMPRIA) in Osteoblasts. J Bone Miner Res 2010, 25, (2), 200-10.

[41] Nakashima, A.; Katagiri, T.; Tamura, M., Cross-talk between Wnt and bone morphogenetic protein 2 (BMP-2) signaling in differentiation pathway of C2C12 myoblasts. J Biol Chem 2005, 280, (45), 37660-8.

[42] Kamiya, N.; Ye, L.; Kobayashi, T.; Mochida, Y.; Yamauchi, M.; Kronenberg, H. M.; Feng, J. Q.; Mishina, Y., BMP signaling negatively regulates bone mass through sclerostin by inhibiting the canonical Wnt pathway. Development 2008, 135, (22), 3801-11.

[43] Liu, Z.; Tang, Y.; Qiu, T.; Cao, X.; Clemens, T. L., A dishevelled-1/Smad1 interaction couples WNT and bone morphogenetic protein signaling pathways in uncommitted bone marrow stromal cells. J Biol Chem 2006, 281, (25), 17156-63.

[44] Zhang, J.; He, X. C.; Tong, W. G.; Johnson, T.; Wiedemann, L. M.; Mishina, Y.; Feng, J. Q.; Li, L., BMP signaling inhibits hair follicle anagen induction by restricting epithelial stem/progenitor cell activation and expansion. Stem Cells 2006.

[45] Hays, E.; Schmidt, J.; Chandar, N., Beta-catenin is not activated by downregulation of PTEN in osteoblasts. In Vitro Cell Dev Biol Anim 2009, 45, (7), 361-70.

[46] Huelsken, J.; Vogel, R.; Erdmann, B.; Cotsarelis, G.; Birchmeier, W., beta-Catenin controls hair follicle morphogenesis and stem cell differentiation in the skin. Cell 2001, 105, (4), 533-45.

[47] Barrow, J. R.; Thomas, K. R.; Boussadia-Zahui, O.; Moore, R.; Kemler, R.; Capecchi, M. R.; McMahon, A. P., Ectodermal Wnt3/beta-catenin signaling is required for the establishment and maintenance of the apical ectodermal ridge. Genes Dev 2003, 17, (3), 394-409.

[48] Rachner, T. D.; Khosla, S.; Hofbauer, L. C., Osteoporosis: now and the future. Lancet 2011, 377, (9773), 1276-87.

[49] Kusu, N.; Laurikkala, J.; Imanishi, M.; Usui, H.; Konishi, M.; Miyake, A.; Thesleff, I.; Itoh, N., Sclerostin is a novel secreted osteoclast-derived bone morphogenetic protein antagonist with unique ligand specificity. J Biol Chem 2003, 278, (26), 241137. 
[50] Winkler, D. G.; Sutherland, M. K.; Geoghegan, J. C.; Yu, C.; Hayes, T.; Skonier, J. E.; Shpektor, D.; Jonas, M.; Kovacevich, B. R.; Staehling-Hampton, K.; Appleby, M.; Brunkow, M. E.; Latham, J. A., Osteocyte control of bone formation via sclerostin, a novel BMP antagonist. Embo J 2003, 22, (23), 6267-76.

[51] Piccolo, S.; Agius, E.; Leyns, L.; Bhattacharyya, S.; Grunz, H.; Bouwmeester, T.; De Robertis, E. M., The head inducer Cerberus is a multifunctional antagonist of Nodal, BMP and Wnt signals. Nature 1999, 397, (6721), 707-10.

[52] Bell, E.; Munoz-Sanjuan, I.; Altmann, C. R.; Vonica, A.; Brivanlou, A. H., Cell fate specification and competence by Coco, a maternal BMP, TGFbeta and Wnt inhibitor. Development 2003, 130, (7), 1381-9.

[53] Itasaki, N.; Jones, C. M.; Mercurio, S.; Rowe, A.; Domingos, P. M.; Smith, J. C.; Krumlauf, R., Wise, a context-dependent activator and inhibitor of Wnt signalling. Development 2003, 130, (18), 4295-305.

[54] van Bezooijen, R. L.; Roelen, B. A.; Visser, A.; van der Wee-Pals, L.; de Wilt, E.; Karperien, M.; Hamersma, H.; Papapoulos, S. E.; ten Dijke, P.; Lowik, C. W., Sclerostin is an osteocyte-expressed negative regulator of bone formation, but not a classical BMP antagonist. J Exp Med 2004, 199, (6), 805-14.

[55] van Bezooijen, R. L.; Svensson, J. P.; Eefting, D.; Visser, A.; van der Horst, G.; Karperien, M.; Quax, P. H.; Vrieling, H.; Papapoulos, S. E.; ten Dijke, P.; Lowik, C. W., Wnt but not BMP signaling is involved in the inhibitory action of sclerostin on BMPstimulated bone formation. J Bone Miner Res 2007, 22, (1), 19-28.

[56] Semenov, M.; Tamai, K.; He, X., SOST is a ligand for LRP5/LRP6 and a Wnt signaling inhibitor. J Biol Chem 2005, 280, (29), 26770-5.

[57] Li, X.; Ominsky, M. S.; Niu, Q. T.; Sun, N.; Daugherty, B.; D'Agostin, D.; Kurahara, C.; Gao, Y.; Cao, J.; Gong, J.; Asuncion, F.; Barrero, M.; Warmington, K.; Dwyer, D.; Stolina, M.; Morony, S.; Sarosi, I.; Kostenuik, P. J.; Lacey, D. L.; Simonet, W. S.; Ke, H. Z.; Paszty, C., Targeted deletion of the sclerostin gene in mice results in increased bone formation and bone strength. J Bone Miner Res 2008, 23, (6), 860-9.

[58] Balemans, W.; Ebeling, M.; Patel, N.; Van Hul, E.; Olson, P.; Dioszegi, M.; Lacza, C.; Wuyts, W.; Van Den Ende, J.; Willems, P.; Paes-Alves, A. F.; Hill, S.; Bueno, M.; Ramos, F. J.; Tacconi, P.; Dikkers, F. G.; Stratakis, C.; Lindpaintner, K.; Vickery, B.; Foernzler, D.; Van Hul, W., Increased bone density in sclerosteosis is due to the deficiency of a novel secreted protein (SOST). Hum Mol Genet 2001, 10, (5), 537-43.

[59] Brunkow, M. E.; Gardner, J. C.; Van Ness, J.; Paeper, B. W.; Kovacevich, B. R.; Proll, S.; Skonier, J. E.; Zhao, L.; Sabo, P. J.; Fu, Y.; Alisch, R. S.; Gillett, L.; Colbert, T.; Tacconi, P.; Galas, D.; Hamersma, H.; Beighton, P.; Mulligan, J., Bone dysplasia sclerosteosis results from loss of the SOST gene product, a novel cystine knotcontaining protein. Am J Hum Genet 2001, 68, (3), 577-89.

[60] Balemans, W.; Patel, N.; Ebeling, M.; Van Hul, E.; Wuyts, W.; Lacza, C.; Dioszegi, M.; Dikkers, F. G.; Hildering, P.; Willems, P. J.; Verheij, J. B.; Lindpaintner, K.; Vickery, B.; Foernzler, D.; Van Hul, W., Identification of a $52 \mathrm{~kb}$ deletion downstream of the SOST gene in patients with van Buchem disease. J Med Genet 2002, 39, (2), 91-7.

[61] Staehling-Hampton, K.; Proll, S.; Paeper, B. W.; Zhao, L.; Charmley, P.; Brown, A.; Gardner, J. C.; Galas, D.; Schatzman, R. C.; Beighton, P.; Papapoulos, S.; Hamersma, H.; Brunkow, M. E., A 52-kb deletion in the SOST-MEOX1 intergenic region on $17 q 12-q 21$ is associated with van Buchem disease in the Dutch population. Am J Med Genet 2002, 110, (2), 144-52. 
[62] Boyden, L. M.; Mao, J.; Belsky, J.; Mitzner, L.; Farhi, A.; Mitnick, M. A.; Wu, D.; Insogna, K.; Lifton, R. P., High bone density due to a mutation in LDL-receptor-related protein 5. N Engl J Med 2002, 346, (20), 1513-21.

[63] Little, R. D.; Carulli, J. P.; Del Mastro, R. G.; Dupuis, J.; Osborne, M.; Folz, C.; Manning, S. P.; Swain, P. M.; Zhao, S. C.; Eustace, B.; Lappe, M. M.; Spitzer, L.; Zweier, S.; Braunschweiger, K.; Benchekroun, Y.; Hu, X.; Adair, R.; Chee, L.; FitzGerald, M. G.; Tulig, C.; Caruso, A.; Tzellas, N.; Bawa, A.; Franklin, B.; McGuire, S.; Nogues, X.; Gong, G.; Allen, K. M.; Anisowicz, A.; Morales, A. J.; Lomedico, P. T.; Recker, S. M.; Van Eerdewegh, P.; Recker, R. R.; Johnson, M. L., A mutation in the LDL receptorrelated protein 5 gene results in the autosomal dominant high-bone-mass trait. Am J Hum Genet 2002, 70, (1), 11-9.

[64] Van Wesenbeeck, L.; Cleiren, E.; Gram, J.; Beals, R. K.; Benichou, O.; Scopelliti, D.; Key, L.; Renton, T.; Bartels, C.; Gong, Y.; Warman, M. L.; De Vernejoul, M. C.; Bollerslev, J.; Van Hul, W., Six novel missense mutations in the LDL receptor-related protein 5 (LRP5) gene in different conditions with an increased bone density. Am J Hum Genet 2003, 72, (3), 763-71.

[65] Babij, P.; Zhao, W.; Small, C.; Kharode, Y.; Yaworsky, P. J.; Bouxsein, M. L.; Reddy, P. S.; Bodine, P. V.; Robinson, J. A.; Bhat, B.; Marzolf, J.; Moran, R. A.; Bex, F., High bone mass in mice expressing a mutant LRP5 gene. J Bone Miner Res 2003, 18, (6), 960-74.

[66] Styrkarsdottir, U.; Halldorsson, B. V.; Gretarsdottir, S.; Gudbjartsson, D. F.; Walters, G. B.; Ingvarsson, T.; Jonsdottir, T.; Saemundsdottir, J.; Snorradottir, S.; Center, J. R.; Nguyen, T. V.; Alexandersen, P.; Gulcher, J. R.; Eisman, J. A.; Christiansen, C.; Sigurdsson, G.; Kong, A.; Thorsteinsdottir, U.; Stefansson, K., New sequence variants associated with bone mineral density. Nat Genet 2009, 41, (1), 15-7.

[67] Huang, Q. Y.; Li, G. H.; Kung, A. W., The -9247 T/C polymorphism in the SOST upstream regulatory region that potentially affects C/EBPalpha and FOXA1 binding is associated with osteoporosis. Bone 2009, 45, (2), 289-94.

[68] Yerges, L. M.; Klei, L.; Cauley, J. A.; Roeder, K.; Kammerer, C. M.; Moffett, S. P.; Ensrud, K. E.; Nestlerode, C. S.; Marshall, L. M.; Hoffman, A. R.; Lewis, C.; Lang, T. F.; Barrett-Connor, E.; Ferrell, R. E.; Orwoll, E. S.; Zmuda, J. M., High-density association study of 383 candidate genes for volumetric BMD at the femoral neck and lumbar spine among older men. J Bone Miner Res 2009, 24, (12), 2039-49.

[69] Morvan, F.; Boulukos, K.; Clement-Lacroix, P.; Roman Roman, S.; Suc-Royer, I.; Vayssiere, B.; Ammann, P.; Martin, P.; Pinho, S.; Pognonec, P.; Mollat, P.; Niehrs, C.; Baron, R.; Rawadi, G., Deletion of a single allele of the Dkk1 gene leads to an increase in bone formation and bone mass. J Bone Miner Res 2006, 21, (6), 934-45.

[70] Li, J.; Sarosi, I.; Cattley, R. C.; Pretorius, J.; Asuncion, F.; Grisanti, M.; Morony, S.; Adamu, S.; Geng, Z.; Qiu, W.; Kostenuik, P.; Lacey, D. L.; Simonet, W. S.; Bolon, B.; Qian, X.; Shalhoub, V.; Ominsky, M. S.; Zhu Ke, H.; Li, X.; Richards, W. G., Dkk1mediated inhibition of Wnt signaling in bone results in osteopenia. Bone 2006, 39, (4), 754-66.

[71] Tian, E.; Zhan, F.; Walker, R.; Rasmussen, E.; Ma, Y.; Barlogie, B.; Shaughnessy, J. D., Jr., The role of the Wnt-signaling antagonist DKK1 in the development of osteolytic lesions in multiple myeloma. N Engl J Med 2003, 349, (26), 2483-94.

[72] Kamiya, N.; Ye, L.; Kobayashi, T.; Lucas, D. J.; Mochida, Y.; Yamauchi, M.; Kronenberg, H. M.; Feng, J. Q.; Mishina, Y., Disruption of BMP signaling in osteoblasts through 
type IA receptor (BMPRIA) increases bone mass. J Bone Miner Res 2008, 23, (12), 2007-17.

[73] Kamiya, N.; Kaartinen, V.; Mishina, Y., Loss-of-function of ACVR1 in osteoblasts increases bone mass and activates canonical Wnt signaling through suppression of Wnt inhibitors SOST and DKK1. Biochem Biophys Res Commun, 2011, 414, (2), 326-30.

[74] Glass, D. A., 2nd; Bialek, P.; Ahn, J. D.; Starbuck, M.; Patel, M. S.; Clevers, H.; Taketo, M. M.; Long, F.; McMahon, A. P.; Lang, R. A.; Karsenty, G., Canonical Wnt signaling in differentiated osteoblasts controls osteoclast differentiation. Dev Cell 2005, 8, (5), 751-64.

[75] Holmen, S. L.; Zylstra, C. R.; Mukherjee, A.; Sigler, R. E.; Faugere, M. C.; Bouxsein, M. L.; Deng, L.; Clemens, T. L.; Williams, B. O., Essential role of beta-catenin in postnatal bone acquisition. J Biol Chem 2005, 280, (22), 21162-8.

[76] Dudley, A. T.; Lyons, K. M.; Robertson, E. J., A requirement for bone morphogenetic protein-7 during development of the mammalian kidney and eye. Genes Dev 1995, 9, (22), 2795-807.

[77] Gu, Z.; Reynolds, E. M.; Song, J.; Lei, H.; Feijen, A.; Yu, L.; He, W.; MacLaughlin, D. T.; van den Eijnden-van Raaij, J.; Donahoe, P. K.; Li, E., The type I serine/threonine kinase receptor ActRIA (ALK2) is required for gastrulation of the mouse embryo. Development 1999, 126, (11), 2551-61.

[78] Luo, G.; Hofmann, C.; Bronckers, A. L.; Sohocki, M.; Bradley, A.; Karsenty, G., BMP-7 is an inducer of nephrogenesis, and is also required for eye development and skeletal patterning. Genes Dev 1995, 9, (22), 2808-20.

[79] Mishina, Y.; Suzuki, A.; Ueno, N.; Behringer, R. R., Bmpr encodes a type I bone morphogenetic protein receptor that is essential for gastrulation during mouse embryogenesis. Genes Dev 1995, 9, (24), 3027-37.

[80] Mishina, Y.; Crombie, R.; Bradley, A.; Behringer, R. R., Multiple roles for activin-like kinase-2 signaling during mouse embryogenesis. Dev Biol 1999, 213, (2), 314-26.

[81] Winnier, G.; Blessing, M.; Labosky, P. A.; Hogan, B. L., Bone morphogenetic protein-4 is required for mesoderm formation and patterning in the mouse. Genes Dev 1995, 9 , (17), 2105-16.

[82] Zhang, H.; Bradley, A., Mice deficient for BMP2 are nonviable and have defects in amnion/chorion and cardiac development. Development 1996, 122, (10), 2977-86.

[83] Mishina, Y.; Starbuck, M. W.; Gentile, M. A.; Fukuda, T.; Kasparcova, V.; Seedor, J. G.; Hanks, M. C.; Amling, M.; Pinero, G. J.; Harada, S.; Behringer, R. R., Bone morphogenetic protein type IA receptor signaling regulates postnatal osteoblast function and bone remodeling. J Biol Chem 2004, 279, (26), 27560-6.

[84] Kronenberg, H. M., Developmental regulation of the growth plate. Nature 2003, 423, (6937), 332-6.

[85] Nakashima, K.; de Crombrugghe, B., Transcriptional mechanisms in osteoblast differentiation and bone formation. Trends Genet 2003, 19, (8), 458-66.

[86] Mackie, E. J.; Ahmed, Y. A.; Tatarczuch, L.; Chen, K. S.; Mirams, M., Endochondral ossification: how cartilage is converted into bone in the developing skeleton. Int J Biochem Cell Biol 2008, 40, (1), 46-62.

[87] Rountree, R. B.; Schoor, M.; Chen, H.; Marks, M. E.; Harley, V.; Mishina, Y.; Kingsley, D. M., BMP receptor signaling is required for postnatal maintenance of articular cartilage. PLoS Biol 2004, 2, (11), e355. 
[88] Yoon, B. S.; Ovchinnikov, D. A.; Yoshii, I.; Mishina, Y.; Behringer, R. R.; Lyons, K. M., Bmpr1a and Bmpr1b have overlapping functions and are essential for chondrogenesis in vivo. Proc Natl Acad Sci U S A 2005, 102, (14), 5062-7.

[89] Tsumaki, N.; Nakase, T.; Miyaji, T.; Kakiuchi, M.; Kimura, T.; Ochi, T.; Yoshikawa, H., Bone morphogenetic protein signals are required for cartilage formation and differently regulate joint development during skeletogenesis. J Bone Miner Res 2002, 17, (5), 898-906.

[90] Retting, K. N.; Song, B.; Yoon, B. S.; Lyons, K. M., BMP canonical Smad signaling through Smad1 and Smad5 is required for endochondral bone formation. Development 2009, 136, (7), 1093-104.

[91] Bandyopadhyay, A.; Tsuji, K.; Cox, K.; Harfe, B. D.; Rosen, V.; Tabin, C. J., Genetic Analysis of the Roles of BMP2, BMP4, and BMP7 in Limb Patterning and Skeletogenesis. PLoS Genet 2006, 2, (12), e216.

[92] Tsuji, K.; Bandyopadhyay, A.; Harfe, B. D.; Cox, K.; Kakar, S.; Gerstenfeld, L.; Einhorn, T.; Tabin, C. J.; Rosen, V., BMP2 activity, although dispensable for bone formation, is required for the initiation of fracture healing. Nat Genet 2006, 38, (12), 1424-9.

[93] Okamoto, M.; Murai, J.; Yoshikawa, H.; Tsumaki, N., Bone morphogenetic proteins in bone stimulate osteoclasts and osteoblasts during bone development. J Bone Miner Res 2006, 21, (7), 1022-33.

[94] Okamoto, M.; Murai, J.; Imai, Y.; Ikegami, D.; Kamiya, N.; Kato, S.; Mishina, Y.; Yoshikawa, H.; Tsumaki, N., Conditional deletion of Bmpr1a in differentiated osteoclasts increases osteoblastic bone formation, increasing volume of remodeling bone in mice. J Bone Miner Res 2011, 26, (10), 2511-22.

[95] Zimmerman, L. B.; De Jesus-Escobar, J. M.; Harland, R. M., The Spemann organizer signal noggin binds and inactivates bone morphogenetic protein 4. Cell 1996, 86, (4), 599-606.

[96] Logan, M.; Martin, J. F.; Nagy, A.; Lobe, C.; Olson, E. N.; Tabin, C. J., Expression of Cre Recombinase in the developing mouse limb bud driven by a Prxl enhancer. Genesis 2002, 33, (2), 77-80.

[97] Tsuji, K.; Cox, K.; Gamer, L.; Graf, D.; Economides, A.; Rosen, V., Conditional deletion of BMP7 from the limb skeleton does not affect bone formation or fracture repair. $J$ Orthop Res 2010, 28, (3), 384-9.

[98] Kanczler, J. M.; Oreffo, R. O., Osteogenesis and angiogenesis: the potential for engineering bone. Eur Cell Mater 2008, 15, 100-14.

[99] Carano, R. A.; Filvaroff, E. H., Angiogenesis and bone repair. Drug Discov Today 2003, 8, (21), 980-9.

[100] Deckers, M. M.; van Bezooijen, R. L.; van der Horst, G.; Hoogendam, J.; van Der Bent, C.; Papapoulos, S. E.; Lowik, C. W., Bone morphogenetic proteins stimulate angiogenesis through osteoblast-derived vascular endothelial growth factor A. Endocrinology 2002, 143, (4), 1545-53.

[101] Cheng, H.; Jiang, W.; Phillips, F. M.; Haydon, R. C.; Peng, Y.; Zhou, L.; Luu, H. H.; An, N.; Breyer, B.; Vanichakarn, P.; Szatkowski, J. P.; Park, J. Y.; He, T. C., Osteogenic activity of the fourteen types of human bone morphogenetic proteins (BMPs). J Bone Joint Surg Am 2003, 85-A, (8), 1544-52.

[102] Phillips, F. M.; Bolt, P. M.; He, T. C.; Haydon, R. C., Gene therapy for spinal fusion. Spine J 2005, 5, (6 Suppl), 250S-258S. 
[103] David, L.; Feige, J. J.; Bailly, S., Emerging role of bone morphogenetic proteins in angiogenesis. Cytokine Growth Factor Rev 2009, 20, (3), 203-12.

[104] Kan, L.; Hu, M.; Gomes, W. A.; Kessler, J. A., Transgenic mice overexpressing BMP4 develop a fibrodysplasia ossificans progressiva (FOP)-like phenotype. Am J Pathol 2004, 165, (4), 1107-15.

[105] Lounev, V. Y.; Ramachandran, R.; Wosczyna, M. N.; Yamamoto, M.; Maidment, A. D.; Shore, E. M.; Glaser, D. L.; Goldhamer, D. J.; Kaplan, F. S., Identification of progenitor cells that contribute to heterotopic skeletogenesis. J Bone Joint Surg Am 2009, 91, (3), 652-63.

[106] Yu, P. B.; Deng, D. Y.; Lai, C. S.; Hong, C. C.; Cuny, G. D.; Bouxsein, M. L.; Hong, D. W.; McManus, P. M.; Katagiri, T.; Sachidanandan, C.; Kamiya, N.; Fukuda, T.; Mishina, Y.; Peterson, R. T.; Bloch, K. D., BMP type I receptor inhibition reduces heterotopic [corrected] ossification. Nat Med 2008, 14, (12), 1363-9.

[107] Medici, D.; Shore, E. M.; Lounev, V. Y.; Kaplan, F. S.; Kalluri, R.; Olsen, B. R., Conversion of vascular endothelial cells into multipotent stem-like cells. Nat Med 2010, 16, (12), 1400-6.

[108] Chan, C. K.; Chen, C. C.; Luppen, C. A.; Kim, J. B.; DeBoer, A. T.; Wei, K.; Helms, J. A.; Kuo, C. J.; Kraft, D. L.; Weissman, I. L., Endochondral ossification is required for haematopoietic stem-cell niche formation. Nature 2009, 457, (7228), 490-4.

[109] Horowitz, M. C.; Lorenzo, J. A., The origins of osteoclasts. Curr Opin Rheumatol 2004, $16,(4), 464-8$.

[110] Kaneko, H.; Arakawa, T.; Mano, H.; Kaneda, T.; Ogasawara, A.; Nakagawa, M.; Toyama, Y.; Yabe, Y.; Kumegawa, M.; Hakeda, Y., Direct stimulation of osteoclastic bone resorption by bone morphogenetic protein (BMP)-2 and expression of BMP receptors in mature osteoclasts. Bone 2000, 27, (4), 479-86.

[111] Simonet, W. S.; Lacey, D. L.; Dunstan, C. R.; Kelley, M.; Chang, M. S.; Luthy, R.; Nguyen, H. Q.; Wooden, S.; Bennett, L.; Boone, T.; Shimamoto, G.; DeRose, M.; Elliott, R.; Colombero, A.; Tan, H. L.; Trail, G.; Sullivan, J.; Davy, E.; Bucay, N.; Renshaw-Gegg, L.; Hughes, T. M.; Hill, D.; Pattison, W.; Campbell, P.; Sander, S.; Van, G.; Tarpley, J.; Derby, P.; Lee, R.; Boyle, W. J., Osteoprotegerin: a novel secreted protein involved in the regulation of bone density. Cell 1997, 89, (2), 30919.

[112] Lacey, D. L.; Timms, E.; Tan, H. L.; Kelley, M. J.; Dunstan, C. R.; Burgess, T.; Elliott, R.; Colombero, A.; Elliott, G.; Scully, S.; Hsu, H.; Sullivan, J.; Hawkins, N.; Davy, E.; Capparelli, C.; Eli, A.; Qian, Y. X.; Kaufman, S.; Sarosi, I.; Shalhoub, V.; Senaldi, G.; Guo, J.; Delaney, J.; Boyle, W. J., Osteoprotegerin ligand is a cytokine that regulates osteoclast differentiation and activation. Cell 1998, 93, (2), 165-76.

[113] Abe, E.; Yamamoto, M.; Taguchi, Y.; Lecka-Czernik, B.; O'Brien, C. A.; Economides, A. N.; Stahl, N.; Jilka, R. L.; Manolagas, S. C., Essential requirement of BMPs-2/4 for both osteoblast and osteoclast formation in murine bone marrow cultures from adult mice: antagonism by noggin. J Bone Miner Res 2000, 15, (4), 663-73.

[114] Itoh, K.; Udagawa, N.; Katagiri, T.; Iemura, S.; Ueno, N.; Yasuda, H.; Higashio, K.; Quinn, J. M.; Gillespie, M. T.; Martin, T. J.; Suda, T.; Takahashi, N., Bone morphogenetic protein 2 stimulates osteoclast differentiation and survival supported by receptor activator of nuclear factor-kappaB ligand. Endocrinology 2001, 142, (8), 3656-62. 


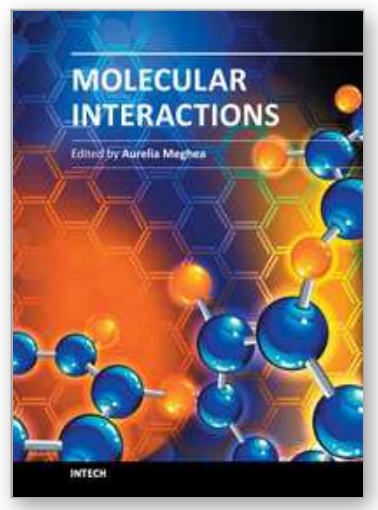

\author{
Molecular Interactions \\ Edited by Prof. Aurelia Meghea
}

ISBN 978-953-51-0079-9

Hard cover, 400 pages

Publisher InTech

Published online 29, February, 2012

Published in print edition February, 2012

In a classical approach materials science is mainly dealing with interatomic interactions within molecules, without paying much interest on weak intermolecular interactions. However, the variety of structures actually is the result of weak ordering because of noncovalent interactions. Indeed, for self-assembly to be possible in soft materials, it is evident that forces between molecules must be much weaker than covalent bonds between the atoms of a molecule. The weak intermolecular interactions responsible for molecular ordering in soft materials include hydrogen bonds, coordination bonds in ligands and complexes, ionic and dipolar interactions, van der Waals forces, and hydrophobic interactions. Recent evolutions in nanosciences and nanotechnologies provide strong arguments to support the opportunity and importance of the topics approached in this book, the fundamental and applicative aspects related to molecular interactions being of large interest in both research and innovative environments. We expect this book to have a strong impact at various education and research training levels, for young and experienced researchers from both academia and industry.

\title{
How to reference
}

In order to correctly reference this scholarly work, feel free to copy and paste the following:

Nobuhiro Kamiya (2012). New Aspect of Bone Morphogenetic Protein Signaling and Its Relationship with Wnt Signaling in Bone, Molecular Interactions, Prof. Aurelia Meghea (Ed.), ISBN: 978-953-51-0079-9, InTech, Available from: http://www.intechopen.com/books/molecular-interactions/new-aspect-of-bone-morphogeneticprotein-signaling-and-its-relationship-with-wnt-signaling-in-bone

\section{INTECH}

open science | open minds

\section{InTech Europe}

University Campus STeP Ri

Slavka Krautzeka 83/A

51000 Rijeka, Croatia

Phone: +385 (51) 770447

Fax: +385 (51) 686166

www.intechopen.com

\section{InTech China}

Unit 405, Office Block, Hotel Equatorial Shanghai

No.65, Yan An Road (West), Shanghai, 200040, China

中国上海市延安西路65号上海国际贵都大饭店办公楼 405 单元

Phone: +86-21-62489820

Fax: +86-21-62489821 
(C) 2012 The Author(s). Licensee IntechOpen. This is an open access article distributed under the terms of the Creative Commons Attribution 3.0 License, which permits unrestricted use, distribution, and reproduction in any medium, provided the original work is properly cited. 